\title{
Editor's introduction to the Guest Editor Pamela Wible
}

\author{
Mariaelena Bartesaghi \\ Department of Communication, University of South Florida, Tampa, FL, USA
}

I want to thank Dr. Wible for agreeing to act as guest editor of this issue. Dr. Pamela Wible is a family physician born into a family of physicians who warned her not to pursue medicine. She soon discovered why - to heal her patients she first had to heal her profession. Fed up with assembly-line medicine, Dr. Wible held town hall meetings where she invited citizens to design their own ideal clinic. Open since 2005, Wible's community clinic has inspired Americans to create ideal clinics and hospitals nationwide. In between treating her own patients and helping doctors launch community clinics, Dr. Wible devotes herself to medical student and physician suicide prevention. She has investigated nearly 1300 doctor suicides and her extensive database and suicide registry reveals highest risk specialties - and solutions. Dr. Wible runs a free doctor suicide hotline and has helped countless medical students and physicians heal from anxiety, depression,
PTSD, and suicidal thoughts so they can enjoy practicing medicine again. Dr. Wible speaks widely on health care delivery and physician suicide prevention. She is the bestselling author of Human Rights Violations in Medicine: A-to-Z Action Guide, Physician Suicide Letters - Answered and Pet Goats \& Pap Smears: 101 Medical Adventures to Open Your Heart \& Mind. Her blogs have been picked up by major media such as The Washington Post and Time Magazine. She has delivered two TED talks, an award-winning NPR interview, and is a subject in the new documentary, Do No Harm: Exposing the Hippocratic Hoax. An inspiring leader and educator of the next generation of physicians, Dr. Wible has been named one of the 2015 Women Leaders in Medicine by the American Medical Student Association and TEDMED calls her the "Physicians' Guardian Angel".

Her introduction to this issue follows.
Correspondence: Mariaelena Bartesaghi, Department of Communication, University of South Florida, CIS 1040, 4202 E. Fowler Ave, Tampa, 33620 FL, USA.

Tel.: +1.813.974.2145 - Fax: +1.813.974.6817.

E-mail: mbartesaghi@usf.edu

Received for publication: 18 October 2019.

Accepted for publication: 8 November 2019.

This work is licensed under a Creative Commons Attribution NonCommercial 4.0 License (CC BY-NC 4.0).

${ }^{\circ}$ Copyright: the Author(s), 2019

Licensee PAGEPress, Italy

Qualitative Research in Medicine \& Healthcare 2019; 3:V

doi:10.4081/qrmh.2019.8921 